\title{
Prevalence and risk factors for stunting and severe stunting among under-fives in North Maluku province of Indonesia Ramli $^{\dagger 1}$, Kingsley E Agho*2, Kerry J Inder ${ }^{\dagger 1}$, Steven J Bowe ${ }^{\dagger 1}$, Jennifer Jacobs ${ }^{\dagger 2}$ and Michael J Dibley ${ }^{\dagger 3}$
}

\begin{abstract}
Address: ${ }^{1}$ Centre for Clinical Epidemiology and Biostatistics, the University of Newcastle, NSW, Australia, ${ }^{2}$ School of Medicine, the University of Western Sydney, NSW, Australia and ${ }^{3}$ School of Public Health, the University of Sydney, NSW, Australia

Email: Ramli - Ramli@studentmail.newcastle.edu.au; Kingsley E Agho* - k.agho@uws.edu.au; Kerry J Inder - Kerry.Inder@newcastle.edu.au; Steven J Bowe - Steven.Bowe@newcastle.edu.au; Jennifer Jacobs - J.Jacobs@uws.edu.au; Michael J Dibley - mdibley@health.usyd.edu.au

* Corresponding author †Equal contributors
\end{abstract}

Published: 6 October 2009

BMC Pediatrics 2009, 9:64 doi:10.1186/147|-2431-9-64

This article is available from: http://www.biomedcentral.com/I47|-243 I/9/64

(C) 2009 Ramli et al; licensee BioMed Central Ltd.

This is an Open Access article distributed under the terms of the Creative Commons Attribution License (http://creativecommons.org/licenses/by/2.0), which permits unrestricted use, distribution, and reproduction in any medium, provided the original work is properly cited.
Received: 28 January 2009
Accepted: 6 October 2009

\begin{abstract}
Background: Adequate nutrition is needed to ensure optimum growth and development of infants and young children. Understanding of the risk factors for stunting and severe stunting among children aged less than five years in North Maluku province is important to guide Indonesian government public health planners to develop nutrition programs and interventions in a post conflict area. The purpose of the current study was to assess the prevalence of and the risk factors associated with stunting and severe stunting among children aged less than five years in North Maluku province of Indonesia.
\end{abstract}

Methods: The health and nutritional status of children aged less than five years was assessed in North Maluku province of Indonesia in 2004 using a cross-sectional multi-stage survey conducted on 750 households from each of the four island groups in North Maluku province. A total of 2168 children aged 0-59 months were used in the analysis.

Results: Prevalence of stunting and severe stunting were $29 \%(95 \% \mathrm{Cl}: 26.0-32.2)$ and $14.1 \%$ (95\%Cl: I I.7- I7.0) for children aged 0-23 months and 38.4\% (95\% Cl: $35.9-4 \mathrm{I} .0)$ and I8.4\% (95\%Cl: 16. I-20.9) for children aged 0-59 months, respectively. After controlling for potential confounders, multivariate analysis revealed that the risk factors for stunted children were child's age in months, male sex and number of family meals per day ( $\leq 2$ times), for children aged 0-23 months, and income (poorest and middle-class family), child's age in months and male sex for children aged 0-59 months. The risk factors for severe stunting in children aged 0-23 months were income (poorest family), male sex and child's age in months and for children aged 0-59 months were income (poorest family), father's occupation (not working), male sex and child's age in months.

Conclusion: Programmes aimed at improving stunting in North Maluku province of Indonesia should focus on children under two years of age, of male sex and from families of low socioeconomic status. 


\section{Background}

The optimal growth and development of infants and young children are fundamental for their future [1]. Stunting, a deficit in height or length relative to a child's age is a major health problem in South Asia where half of children aged less than five years are stunted [2]. In Indonesia, $37 \%$ of children aged less than five years are stunted [3]. Promoting better eating habits in an effort to improve nutrition is one of the most challenging tasks in Indonesia as malnutrition remains one of the most important public health problems facing almost every district [4].

In Indonesia, like many developing countries, the most common nutritional problems in infancy and early childhood are stunting, wasting; iron-deficiency anaemia, poverty and low birth weight $[5,6]$. Malnutrition during the first 2 years of life can lead to mortality and morbidity in childhood $[7,8]$ and is one of the most preventable risk factors for mortality [9].

Past studies have also shown that lower intelligence quotient (IQ), mother's height, male sex, mother and father level of education, poverty, socioeconomic status, residence, child care behaviour (inadequate complimentary feeding and breastfeeding), cultural beliefs, access to health care and environmental ecosystems $[10,11]$ are factors associated with stunting in children aged less than five years.

Despite the persistently high prevalence of stunted children in Indonesia, there is a lack of information about the prevalence and risk factors associated with stunted and severely stunted children in the North Maluku province of Indonesia using the new Growth reference from the World Health Organisation [12]. This province is an area in Indonesia that in 2004 had recently emerged from a period of prolonged civil conflict. This paper assesses the prevalence and risk factors associated with stunting and severe stunting in children aged 0-59 months old in North Maluku province of Indonesia.

\section{Methods \\ Study location}

The study covered all areas in the North Maluku province of Indonesia (see Figure 1) [13] with a total population of about 920,000 people in 2006 [14,15], divided into four island groups The first island group consists of the districts of Ternate and Tidore with a total population of about 241,000 people. The second island group consists of the districts of Central Halmahera and East Halmahera with a total population of about 95,000 people. The third island group consists of the districts of West Halmahera and North Halmahera with a total population of about 276,000 people. The forth island group consists of the districts of South Halmahera and Sula-Isles with a total population of about 308,000 people [15].

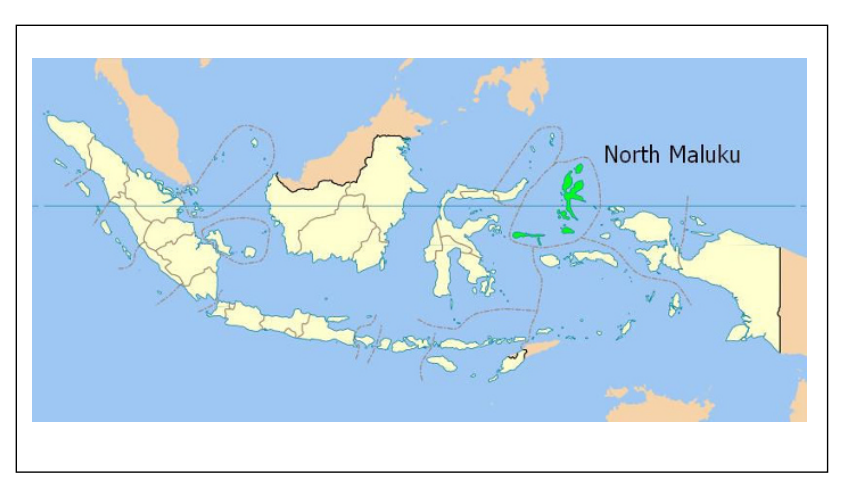

Figure I

Map of Indonesia showing North Maluku Province. (Source: Wikipedia, 2008)

\section{Study design}

A cross-sectional survey was conducted in 2004 on 3000 households from the four island groups in North Maluku province. A multistage cluster sampling technique was used for selecting the study sample in which North Maluku province was grouped into four island groups with eight districts in total.

\section{Selection of subjects}

The four island groups within North Maluku province were used to select the study areas. In the first stage, two districts were randomly selected based on probability proportional to size from each island group [15]. In the second stage, subdistricts (referred to as clusters) were randomly selected from each district. In the third stage, Puskesmas (Community Public Health Services) were selected randomly from each subdistrict and finally, the villages were randomly selected from Puskesmas. Household selection in each cluster was randomly taken by using the sampling frame of every $10^{\text {th }}$ household with the nearest household from the village health service (Pustu) as the starting point. Comprehensive details of the study districts and selection criteria have been reported elsewhere [16]. In total, 50 households were selected in each cluster and 15 clusters in each island group, yielding a total of 750 households from each island group.

\section{Stunting (Height-for-age)}

The nutritional status of children less than five years of age was measured anthropometrically. Length was measured for children aged less than two years old and height for those two years of age and older. Length was measured using a wooden stadiometer to the nearest $0.1 \mathrm{~cm}$ and height was measured using Microtoice tape to the nearest $0.1 \mathrm{~cm}$ [17]. The height-for-age measurement status was expressed in Standard Deviation (SD) units (Z-score) from the median of the reference population. Children with a measurement of <-2 SD units from the median of the reference population were considered short for their 
age (stunted) and children with measurement of <-3SD units from the median of the reference population were considered to be severely stunted.

\section{Socioeconomic factors}

A structured household questionnaire was used for collecting information about the following family level factors: region (urban and rural), district (total of eight), father's level of education (completed elementary school [ 6 years of schooling], completed middle school [9 years of schooling] and completed high school [12 years of schooling]; mother's level of education; parental education (both with higher education, father with high education, mother with high education, neither with high education); father's occupation, mother's occupation; parental occupation; household wealth index (calculated from household's ownership of consumer items including refrigerators, VCR players, satellite dishes, televisions, lounges, boats, cars, motorcycles; flooring material; type of drinking-water source; toilet facilities; and other characteristics that are related to wealth status - categorised into poorest, middle and least poor); number of household members in the family and number of family meals per day. In addition, the following child level factors were collected: child's age in months; gender; provision of nutritional status information during pregnancy and number of antenatal visits. The questionnaires were administered after a signed informed consent was collected. The questionnaires were checked daily for accuracy, consistency, and completeness by field supervisors.

\section{Ethical permission}

This study had the approval of the Ministry of Health in Indonesia and the protocol for secondary data analysis was approved by Human Ethics Research Committee, University of Newcastle - Australia.

\section{Statistical analyses}

Data were entered into a computerised database and cleaned using the data entry program EPIINFO [18]. Data on nutritional status were analysed based on the new growth reference from the World Health Organisation. The household ownership of consumer items described above were used in constructing the wealth index scores by using a method similar to that described by Filmer and Pritchett [19] and were divided into three categories. The bottom $40 \%$ of the households was referred to as the poorest households, the next $40 \%$ as the middle-class households, and the top $20 \%$ as the least poor households. The analysis for stunted and severely stunted children was categorised into two groups (1) children aged 023 months, and (2) children aged 0-59 months.

To determine the level of stunting and severe stunting the dependent variable was expressed as a dichotomous vari- able: category 0 if not stunted ( $\geq-2 S D)$ or severely stunted $(\geq-3 S D)$ and category 1 if stunted $(<-2 S D)$ or severely stunted $(<-3 S D)$.

Firstly, univariate binary logistic regression analysis was performed to examine the association between stunted and severely stunted children aged 0-23 months and stunted children 0-59 months. Secondly, the factors associated with stunting and severe stunting were examined in a multiple logistic regression model. A stepwise backward elimination approach was applied. At the start variables were selected for inclusion in the model if their univariate analysis $\mathrm{p}$-value was $<=0.25$. Only variables which were statistically associated with stunted and severely stunted children $(\mathrm{p}<0.05)$ remained in the final model. Unadjusted and adjusted odds ratios from a logistic model are presented with 95\% confidence intervals. The 'SVY' commands from Stata version 9.2 (Stata Corp) were used for data analysis to adjust for the cluster sampling design and appropriate sampling weights.

\section{Results}

\section{Univariate Analyses}

Table 1 presents the prevalence of stunting and severe stunting in children aged 0-23 months and 0-59 months, respectively. Table 1 reveals that the child's age and gender were significantly associated with stunting in children aged 0-23 months while the mother's education, the household wealth index, the child's age and gender were significantly associated with severe stunting in children aged 0-23 months.

For children aged 0-59 months, parental education (only mothers with higher education and neither parent with higher education), household wealth index (poorest), region (urban), child's age and males were statistically significantly associated with stunting. While, father's occupation (not working), parental education (neither parent with higher education), household wealth index (poorest), child's age (24-29 months old) and males reported higher prevalence of severe stunting. The overall prevalence of being stunted and severely stunted was $29 \%$ and $14.1 \%$ for children aged $0-23$ months and $38.4 \%$ and $18.4 \%$ for children aged 0-59 months (see Table 1), respectively.

\section{Multivariate Analyses}

Tables 2 and 3 shows the unadjusted and adjusted odds ratios for the association between stunted and severely stunted children and socioeconomic characteristics of children aged 0-23 months children aged 0-59 months.

\section{Risk factors for stunting}

The odds for stunted children aged 0-23 months was 26 percent lower in families that provided at least three meals 
Table I: Prevalence of stunting and severe stunting in children aged $\mathbf{0 - 2 3}$ months and $\mathbf{0 - 5 9}$ months

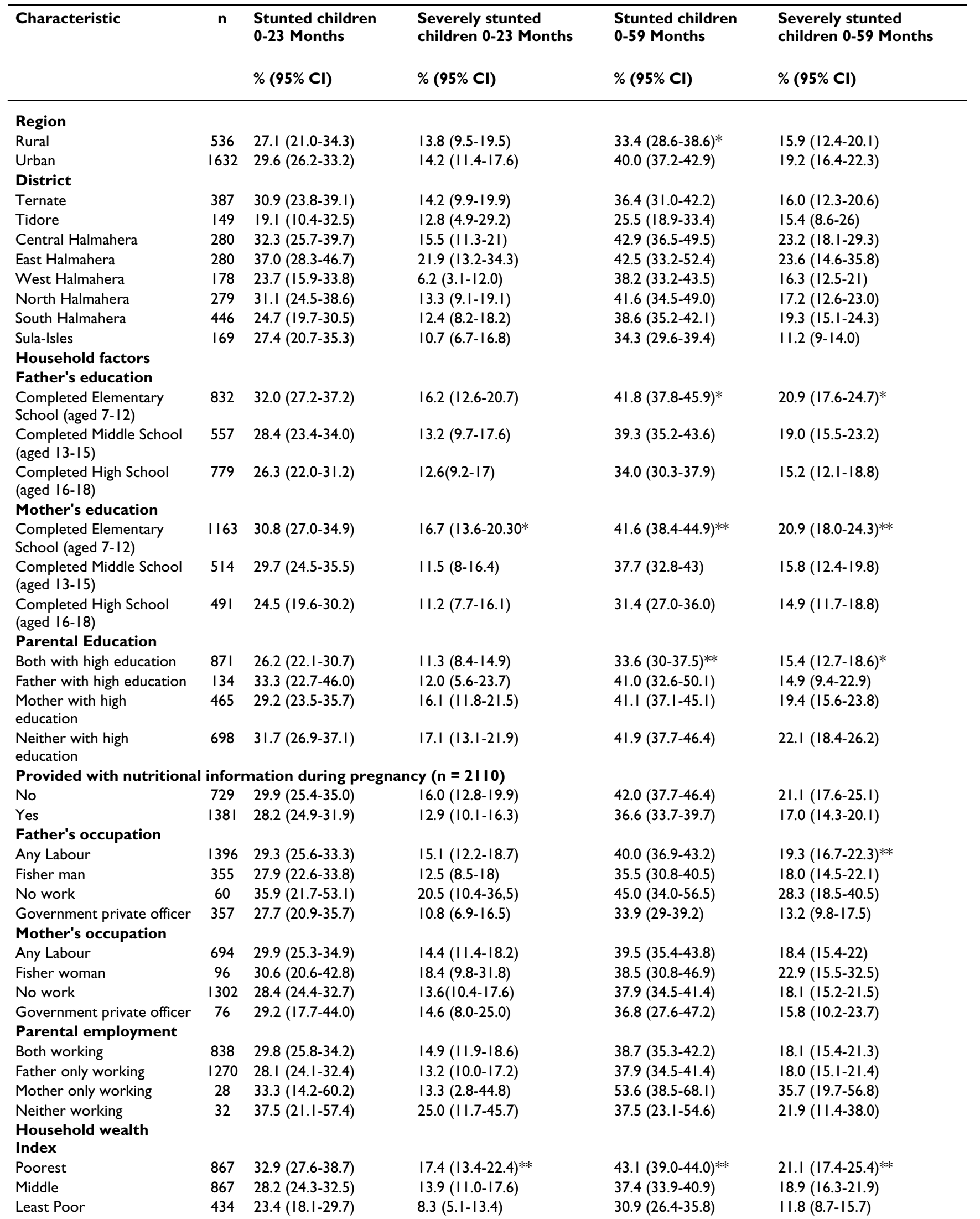


Table I: Prevalence of stunting and severe stunting in children aged 0-23 months and 0-59 months (Continued)

\begin{tabular}{|c|c|c|c|c|c|}
\hline \multicolumn{6}{|c|}{ Household member } \\
\hline$\leq 5$ members & 1359 & $31.3(27.6-35.4)$ & $14.8(11.6-18.7)$ & $39.3(36.2-42.5)$ & | $8.5(|5.7-2| .7)$ \\
\hline $6-12$ members & 809 & $24.9(21-29.4)$ & $12.9(10.1-16.4)$ & $36.8(33.0-40.8)$ & $18.1(15.2-21.3)$ \\
\hline \multicolumn{6}{|c|}{$\begin{array}{l}\text { Number of family } \\
\text { Meals per day }\end{array}$} \\
\hline 2 Times & 675 & $24.9(20.5-29.8)$ & $13.1(9.9-17.1)$ & $36.3(32.2-40.6)$ & $17.6(|4.3-2| .6)$ \\
\hline$>2$ Times & 1493 & $30.8(27.0-34.8)$ & $14.5(11.5-18.2)$ & $39.3(36.22-42.5)$ & $18.7(16-21.8)$ \\
\hline \multicolumn{6}{|c|}{ Child level factors } \\
\hline \multicolumn{6}{|c|}{ Child's age in category } \\
\hline $0-5$ & 266 & $12.8(9.1-17.7)^{* * * *}$ & $7.9(5.6-11.0)^{* * *}$ & $12.8(9.1-17.7)^{* * *}$ & $7.9(5.6-11.0)^{* * *}$ \\
\hline $6-11$ & 365 & $24.1(19.3-29.7)$ & $10.1(5.6-1 \mid .0)^{* * *}$ & $24.1(19.3-29.7)$ & $10.1(6.6-15.2)$ \\
\hline $12-17$ & 318 & $33.9(28.6-39.7)$ & $15.7(5.6-|| .0)^{* * *}$ & $33.9(28.6-39.7)$ & $15.7(\mid 1.7-20.8)$ \\
\hline $18-23$ & 234 & $48.3(40.3-56.3)$ & $25.2(5.6-11.0)^{* * *}$ & $48.3(40.3-56.3)$ & $25.2(18.8-32.9)$ \\
\hline $24-29$ & 238 & & & $48.7(42.2-55.4)$ & $26.5(20.4-33.6)$ \\
\hline $30-35$ & 169 & & & $51.5(42.9-60.0)$ & $23.1(16.8-30.8)$ \\
\hline $36-41$ & 215 & & & $52.6(45.9-59.1)$ & $25.6(20.5-31.5)$ \\
\hline $42-47$ & 147 & & & $47.6(37.7-57.7)$ & $19.7(13-28.8)$ \\
\hline $48-53$ & 135 & & & $49.6(39.9-59.4)$ & $23.7(16.8-32.3)$ \\
\hline $54-59$ & 81 & & & $44.4(34.6-54.8)$ & I6.I (8.7-27.6) \\
\hline \multicolumn{6}{|l|}{ Gender } \\
\hline Male & 1115 & $32.2(28.0-36.7)^{*}$ & $16.7(|3.2-2| . \mid)^{* *}$ & $41.4(37.9-44.8)^{*}$ & $20.5(17.4-24.1)^{* *}$ \\
\hline Female & 1053 & $25.6(21.6-30.1)$ & II.3 (8.9-|4.3) & $35.2(31.8-38.8)$ & 16.1 (13.7-18.7) \\
\hline \multicolumn{6}{|c|}{$\begin{array}{l}\text { Antenatal visit } \\
(n=2110)\end{array}$} \\
\hline No & 91 & $39.6(27.2-53.4)$ & $16.7(7.6-32.7)$ & $44.0(35.1-53.2)$ & $23.1(15.4-33.1)$ \\
\hline Yes & 2019 & $28.4(25.4-31.5)$ & $16.7(11.5-16.6)$ & $38.2(35.6-40.9)$ & $18.2(15.9-20.8)$ \\
\hline Overall & & $29.0(26.0-32.2)$ & $16.7(11.7-17.0)$ & $38.4(35.9-4 \mid .0)$ & I8.4 (I6.I-20.9) \\
\hline
\end{tabular}

$* P<0.05 ; * * P<0.01, * * * P<0.001 ; X^{2}$-test was applied to test statistical significance

Weighted total was 2168 otherwise stated within brackets

per day. Increased child age in months was statistically associated with stunting in children aged $0-23$ months (adjusted OR $($ AOR $)=1.11,95 \% \mathrm{CI}: 1.08-1.14 ; \mathrm{p}<$ $0.001)$ and girls had reduced odds of being stunted compared to boys $(\mathrm{AOR}=0.67,95 \% \mathrm{CI}: 0.50-0.89 ; \mathrm{p}=$ $0.006)$.

Children aged 0-59 months from families in the least poor or middle household wealth index categories had reduced odds of being stunted compared to those from the poorest families. Increased age of the child was statistically associated with stunting in children aged 0-59 months (AOR $=1.03,95 \%$ CI: $1.02-1.04 ; \mathrm{p}<0.001$ ). Girls aged 0-59 months had statistically significantly reduced odds of being stunted compared to boys aged 059 months (AOR $=0.72,95 \%$ CI: $0.58-0.90 ; \mathrm{p}=0.005)$.

\section{Risk factors for severe stunting}

As shown in Table 3 the AOR indicated that children aged 0-23 months from families in the least poor or middle household wealth index categories had reduced odds of being severely stunted compared to those from the poorest families. Increasing age of the child was significantly associated with severe stunting (AOR $=1.08,95 \% \mathrm{CI}: 1.05$ - 1.12; $\mathrm{p}<0.001)$. Boys aged $0-23$ months had increased odds of being severely stunted compared with girls aged 023 months (AOR $=0.58,95 \% \mathrm{CI}: 0.42-0.81 ; \mathrm{p}=0.002)$.

Children aged 0-59 months from least poor families had reduced odds of being severely stunted $(\mathrm{AOR}=0.52$, 95\%CI: 0.33 - 0.83; $\mathrm{p}=0.005$ ) compared with those from middle and poorest families. Increasing age of the child was significantly associated with severe stunting in children aged 0-59 months (AOR $=1.02,95 \% \mathrm{CI}$ : $1.01-1.03$; $\mathrm{p}<0.001$ ). Boys aged $0-59$ months had increased odds of being severely stunted compared to girls aged 0-59 months (AOR $=0.72,95 \% \mathrm{CI}: 0.58-0.90 ; \mathrm{p}=0.005)$.

\section{Discussion}

This paper presents data on the prevalence and risk factors associated with stunting and severe stunting in children in North Maluku province of Indonesia. This is the first study to assess the prevalence and factors associated with stunting and severe stunting in children aged less than five years in North Maluku province of Indonesia.

The prevalence of stunting in children in this population was high with $29 \%$ of the children aged 0-23 months and $38.4 \%$ of the children aged $0-59$ months being stunted while, $14.1 \%$ and $18.4 \%$, respectively were severely 
Table 2: Risk factors for stunting in children aged 0-23 months and 0-59 months

\begin{tabular}{|c|c|c|c|c|}
\hline \multirow[t]{2}{*}{ Characteristic } & \multicolumn{2}{|c|}{ Stunted children 0-23 Months } & \multicolumn{2}{|c|}{ Stunted children 0-59 Months } \\
\hline & Unadjusted OR (95\% Cl) & $\begin{array}{c}\text { Adjusted OR } \\
\text { (AOR) }(95 \% \mathrm{Cl})\end{array}$ & Unadjusted OR (95\% Cl) & AOR $(95 \% \mathrm{Cl})$ \\
\hline \multicolumn{5}{|l|}{ Region } \\
\hline Rural & 1.00 & & 1.00 & \\
\hline Urban & $1.13(0.77-1.65)$ & & $1.33(1.03-1.71)$ & \\
\hline \multicolumn{5}{|l|}{ District } \\
\hline Ternate & 1.00 & & 1.00 & \\
\hline Tidore & $0.53(0.24-1.17)$ & & $0.60(0.38-0.94)$ & \\
\hline Central Halmahera & $1.06(0.66-1.72)$ & & $1.31(0.91-1.88)$ & \\
\hline East Halmahera & $1.31(0.76-2.24)$ & & $1.29(0.81-2.06)$ & \\
\hline West Halmahera & $0.69(0.38-1.28)$ & & $1.08(0.78-1.50)$ & \\
\hline North Halmahera & I.0I (0.62-I.64) & & $1.24(0.84-1.83)$ & \\
\hline South Halmahera & $0.73(0.46-1.16)$ & & $1.10(0.82-1.45)$ & \\
\hline Sula-Isles & $0.84(0.50-\mathrm{I} .4 \mathrm{I})$ & & $0.91(0.66-1.26)$ & \\
\hline \multicolumn{5}{|l|}{$\begin{array}{l}\text { Household factors Father's } \\
\text { education }\end{array}$} \\
\hline $\begin{array}{l}\text { Completed Elementary School } \\
\text { (aged 7-12) }\end{array}$ & 1.00 & & 1.00 & \\
\hline $\begin{array}{l}\text { Completed Middle School } \\
\text { (aged 13-15) }\end{array}$ & $0.84(0.59-\mid .2 I)$ & & $0.90(0.7 \mid-1.14)$ & \\
\hline $\begin{array}{l}\text { Completed High School } \\
\text { (aged 16-18) }\end{array}$ & $0.76(0.55-1.05)$ & & $0.70(0.57-0.91)$ & \\
\hline \multicolumn{5}{|l|}{ Mother's Education } \\
\hline $\begin{array}{l}\text { Completed Elementary School } \\
\text { (aged 7-12) }\end{array}$ & 1.00 & & 1.00 & \\
\hline $\begin{array}{l}\text { Completed Middle School } \\
\text { (aged I3-15) }\end{array}$ & $0.95(0.69-\mid .31)$ & & $0.85(0.66-1.09)$ & \\
\hline $\begin{array}{l}\text { Completed High School } \\
\text { (aged 16-18) }\end{array}$ & $0.73(0.55-0.97)$ & & $0.64(0.50-0.83)$ & \\
\hline \multicolumn{5}{|l|}{ Parental Education } \\
\hline Both with high education & 1.00 & & 1.00 & \\
\hline Father with high education & I.4I (0.78-2.54) & & $1.37(0.92-2.04)$ & \\
\hline Mother with high education & $1.17(0.83-1.64)$ & & $1.38(1.09-1.73)$ & \\
\hline Neither with high education & $\mathrm{I} .3 \mathrm{I}(0.96-\mathrm{I} .80)$ & & $1.43(1.11-1.84)$ & \\
\hline \multicolumn{5}{|c|}{ Provided with nutritional information during pregnancy } \\
\hline No & 1.00 & & 1.00 & \\
\hline Yes & $0.78(0.56-1.07)$ & & $0.77(0.57-1.03)$ & \\
\hline \multicolumn{5}{|l|}{ Father's occupation } \\
\hline Any Labour & 1.00 & & 1.00 & \\
\hline Fisher man & $0.93(0.66-1.32)$ & & $0.83(0.65-1.06)$ & \\
\hline No work & $1.35(0.65-2.80)$ & & $1.23(0.77-1.96)$ & \\
\hline Government private officer & $0.92(0.62-1.38)$ & & $0.77(0.60-0.99)$ & \\
\hline \multicolumn{5}{|l|}{ Mother's occupation } \\
\hline Any Labour & 1.00 & & 1.00 & \\
\hline Fisherwoman & $\mathrm{I} .03(0.58-\mathrm{I} .83)$ & & $0.96(0.65-1.42)$ & \\
\hline No work & $0.93(0.69-1.25)$ & & $0.93(0.75-1.17)$ & \\
\hline Government private officer & $0.96(0.49-1.92)$ & & $0.89(0.55-1.46)$ & \\
\hline \multicolumn{5}{|l|}{ Parental employment } \\
\hline Both working & 1.00 & & 1.00 & \\
\hline Father only working & $0.92(0.70-1.2 I)$ & & $0.97(0.79-1.18)$ & \\
\hline Mother only working & $1.18(0.39-3.59)$ & & $1.83(0.97-3.47)$ & \\
\hline Neither working & $1.41(0.62-3.20)$ & & $0.95(0.47-1.92)$ & \\
\hline \multicolumn{5}{|l|}{ Household wealth Index } \\
\hline Poorest & 1.00 & & 1.00 & 1.00 \\
\hline Middle & $0.80(0.58-1.10)$ & & $0.87(0.65-1.16)$ & $0.78(0.63-0.98)$ \\
\hline Least Poor & $0.62(0.41-0.94)$ & & $0.50(0.33-0.75)$ & $0.62(0.45-0.85)$ \\
\hline \multicolumn{5}{|l|}{ Household member } \\
\hline$\leq 5$ members & 1.00 & & 1.00 & \\
\hline $6-12$ members & $0.73(0.56-0.95)$ & & $0.90(0.73-I . I I)$ & \\
\hline
\end{tabular}


Table 2: Risk factors for stunting in children aged 0-23 months and 0-59 months (Continued)

\begin{tabular}{lccc}
\hline Family Meals per day & & & 1.00 \\
2 Times & 1.00 & $0.70(0.50-0.99)$ & $0.88(0.70-1.11)$ \\
$>2$ Times & $0.74(0.54-1.02)$ & $1.11(1.08-1.14)$ & $1.03(1.02-1.04)$ \\
$\begin{array}{l}\text { Child level factors } \\
\text { Child's age (months) }\end{array}$ & $1.10(1.07-1.14)$ & 1.00 & 1.00 \\
Gender & 1.00 & $0.67(0.50-0.89)$ & $0.77(0.63-0.95)$ \\
Male & $0.73(0.54-0.97)$ & & $0.74(0.59-0.93)$ \\
Female & 1.00 & & 1.00 \\
Antenatal visit & $0.89(0.60-1.32)$ & & $0.77(0.57-1.03)$ \\
No & & & $1.00-1.04)$ \\
Yes & & & \\
\hline
\end{tabular}

stunted. This level of stunting in North Maluku was higher than the national level among children aged 0-59 months of $28.6 \%$ reported in 2004 [20].

The prevalence of stunting and severe stunting was higher in children aged 24-59 months (50\% vs 24\%, respectively) than those children aged 0-23 months. This findings is similar to the results from Bangladesh, India and Pakistan [21-23] where children aged 24-59 months were found to be at a greater risk of being stunted. This suggests that for children aged 24-59 months stunting is not likely to be reversible [24]. Our findings support the previous assertions that the prevalence of stunting remains constant after 2 or 3 years of life [25].

Comparing the present study with children in four regions (Africa; Asia, Latin and South America), the prevalence of stunting in children 0-59 months in North Maluku province of Indonesia was slightly lower than that of Africa (40.1\%), higher in Asia (31.3\%), Latin America (16.1\%) and South America (13.8\%)[8]. These differences in prevalence likely result from a combination of factors like environmental, cultural differences and prolonged civil conflicts or war.

The results indicate that the gender of the child is a strong predictor of stunting and severe stunting in children aged 0-23 months and children aged 0-59 months. Girls had lower odds of becoming stunted or severely stunted compared to boys which supports the findings of other studies [26-28]. During infancy and childhood, girls were less likely to become stunted and severely stunted than boys and infant girls survive in greater numbers than infant boys in most developing countries including Indonesia [26-28].

Multivariate analyses identified that the following factors were statistically significantly associated with stunting and severe stunting for all of the three age categories after controlling for potential confounders: (a) number of family meals per day ( 2 meals per day); (b) child's age in months; (c) male sex; (d) household wealth (poorest); (e) parental employment (not working) and (f) district (Cen- tral and South Halmahera). These findings support similar studies indicating that mother's education, household wealth, gender, age and employment were significantly associated with stunted children [28-30].

This study suggests that stunting in children in North Maluku may be reduced by improving mother's education, mother's nutritional information and reducing poverty. This study highlights the need to provide special attention to reducing stunting in the Central and South Halmahera districts. Interventions for improving the provision of education for girls are required as lack of education appears to be a major risk factor for stunting in children in North Maluku province.

A number of important limitations due to the nature of the data used (secondary data analysis) needs to be considered. Firstly, there is no dietary intake data to support our findings. Secondly, this study used only two main characteristics (family and child level factors). Finally, the design is cross-sectional and reports only a "snapshot" of the frequency of stunting and severe stunting. Hence no strong conclusions can be made as to the possible causes of stunting and severe stunting.

Despite these limitations, the findings from this study contribute to our understanding of the factors associated with stunting and severe stunting in children aged 0-59 months in North Maluku, Indonesia. The findings in this study will assist the local government in North Maluku develop an appropriate intervention for the children aged 0-59 months and their parents. It may also help the Indonesian government public health planners develop a national nutrition program and interventions targeting young children especially in post conflict areas in eastern Indonesia. However, further research is required to understand the dietary and other determinants (including environmental risk factors) of stunting in North Maluku province of Indonesia.

\section{Conclusion}

Childhood malnutrition remains a major public health problem in Indonesia. Results from this cross-sectional 
Table 3: Risk factors for severe stunting in children aged 0-23 months and 0-59 months

\begin{tabular}{|c|c|c|c|c|}
\hline \multirow[t]{2}{*}{ Characteristic } & \multicolumn{2}{|c|}{ Severely stunted children $0-23$ Months } & \multicolumn{2}{|c|}{ Severely stunted children 0-59 Months } \\
\hline & Unadjusted OR (95\% Cl) & Adjusted OR (95\% Cl) & Unadjusted OR $(95 \% \mathrm{CI})$ & Adjusted OR (95\% Cl) \\
\hline \multicolumn{5}{|l|}{ Region } \\
\hline Rural & 1.00 & & 1.00 & \\
\hline Urban & $1.04(0.64-1.70)$ & & $1.33(1.03-1.71)$ & \\
\hline \multicolumn{5}{|l|}{ District } \\
\hline Ternate & 1.00 & & 1.00 & \\
\hline Tidore & $0.88(0.29-2.68)$ & & $0.60(0.38-0.94)$ & \\
\hline Central Halmahera & $1.10(0.64-1.92)$ & & $1.31(0.91-1.88)$ & \\
\hline East Halmahera & $1.70(0.81-3.56)$ & & $1.29(0.81-2.06)$ & \\
\hline West Halmahera & $0.40(0.18-0.92)$ & & $1.08(0.78-1.50)$ & \\
\hline North Halmahera & $0.93(0.51-1.68)$ & & $1.24(0.84-1.83)$ & \\
\hline South Halmahera & $0.85(0.46-1.57)$ & & $1.10(0.82-1.45)$ & \\
\hline Sula-Isles & $0.72(0.37-\mathrm{I} .40)$ & & $0.91(0.66-1.26)$ & \\
\hline \multicolumn{5}{|l|}{$\begin{array}{l}\text { Household factors } \\
\text { Father's education }\end{array}$} \\
\hline $\begin{array}{l}\text { Completed Elementary } \\
\text { School (aged 7-12) }\end{array}$ & 1.00 & & 1.00 & \\
\hline $\begin{array}{l}\text { Completed Middle School } \\
\text { (aged 13-15) }\end{array}$ & $0.78(0.48-1.26)$ & & $0.89(0.64-1.24)$ & \\
\hline $\begin{array}{l}\text { Completed High School } \\
\text { (aged 16-18) }\end{array}$ & $0.75(0.5 \mathrm{I}-\mathrm{I} .10)$ & & $0.68(0.50-0.91)$ & \\
\hline \multicolumn{5}{|l|}{ Mother's education } \\
\hline $\begin{array}{l}\text { Completed Elementary } \\
\text { School (aged 7-12) }\end{array}$ & 1.00 & & 1.00 & \\
\hline $\begin{array}{l}\text { Completed Middle School } \\
\text { (aged 13-15) }\end{array}$ & $0.65(0.41-1.05)$ & & $0.70(0.51-0.98)$ & \\
\hline $\begin{array}{l}\text { Completed High School } \\
\text { (aged 16-18) }\end{array}$ & $0.63(0.43-0.92)$ & & $0.66(0.49-0.88)$ & \\
\hline \multicolumn{5}{|l|}{ Parental education } \\
\hline Both with high education & 1.00 & & 1.00 & \\
\hline Father with high education & $1.07(0.44-2.63)$ & & $1.37(0.92-2.04)$ & \\
\hline Mother with high education & I.5I (0.97-2.35) & & $1.38(1.09-1.73)$ & \\
\hline Neither with high education & $1.62(1.09-2.4 \mathrm{I})$ & & $1.43(1.11-1.84)$ & \\
\hline \multicolumn{5}{|c|}{ Provided with nutritional information during pregnancy } \\
\hline No & 1.00 & & 1.00 & \\
\hline Yes & $0.78(0.56-1.07)$ & & $0.77(0.57-1.03)$ & \\
\hline \multicolumn{5}{|l|}{ Father's occupation } \\
\hline Any Labour & 1.00 & & 1.00 & 1.00 \\
\hline Fisherman & $0.80(0.49-1.32)$ & & $0.92(0.70-1.19)$ & $1.13(0.85-1.52)$ \\
\hline No work & $1.45(0.63-3.34)$ & & $1.65(0.92-2.94)$ & $2.04(1.17-3.53)$ \\
\hline Government private officer & $0.68(0.42-1.10)$ & & $0.63(0.45-0.89)$ & $0.79(0.55-1.14)$ \\
\hline \multicolumn{5}{|l|}{ Mother's occupation } \\
\hline Any Labour & 1.00 & & 1.00 & \\
\hline Fisherwoman & $1.33(0.62-2.88)$ & & I.3I (0.78-2.22) & \\
\hline No work & $0.93(0.63-1.39)$ & & $0.98(0.75-1.28)$ & \\
\hline Government private officer & $\mathrm{I} .0 \mathrm{I}(0.5 \mathrm{I}-2.0 \mathrm{I})$ & & $0.83(0.49-1.40)$ & \\
\hline \multicolumn{5}{|l|}{ Parental employment } \\
\hline Both working & 1.00 & & 1.00 & \\
\hline Father only working & $0.87(0.60-1.26)$ & & $0.97(0.79-\mathrm{I} .18)$ & \\
\hline Mother only working & $0.88(0.16-4.74)$ & & $1.83(0.97-3.47)$ & \\
\hline Neither working & $1.90(0.72-5.01)$ & & $0.95(0.47-1.92)$ & \\
\hline \multicolumn{5}{|l|}{ Household wealth Index } \\
\hline Poorest & 1.00 & 1.00 & 1.00 & 1.00 \\
\hline Middle & $0.77(0.5 \mathrm{I}-\mathrm{I} .15)$ & $0.78(0.52-\mathrm{I} .18)$ & $0.87(0.65-\mathrm{I} .16)$ & $0.89(0.66-1.20)$ \\
\hline Least Poor & $0.43(0.24-0.79)$ & $0.42(0.23-0.79)$ & $0.50(0.33-0.75)$ & $0.52(0.33-0.82)$ \\
\hline \multicolumn{5}{|l|}{ Household member } \\
\hline$\leq 5$ members & 1.00 & & 1.00 & \\
\hline 6-12 members & $0.86(0.59-1.24)$ & & $0.90(0.73-1.11)$ & \\
\hline
\end{tabular}


Table 3: Risk factors for severe stunting in children aged 0-23 months and 0-59 months (Continued)

\begin{tabular}{|c|c|c|c|c|}
\hline \multicolumn{5}{|l|}{ Family Meals per day } \\
\hline 2 Times & 1.00 & & 1.00 & \\
\hline$>2$ Times & $0.89(0.60-1.32)$ & & $0.93(0.69-1.26)$ & \\
\hline \multicolumn{5}{|l|}{ Child level factors } \\
\hline Child's age (months) & $1.08(1.05-1.12)$ & $1.08(1.05-1.12)$ & $1.03(1.02-1.04)$ & $1.02(1.01-1.03)$ \\
\hline \multicolumn{5}{|l|}{ Gender } \\
\hline Male & 1.00 & 1.00 & 1.00 & 1.00 \\
\hline Female & $0.63(0.45-0.89)$ & $0.58(0.42-0.81)$ & $0.77(0.63-0.95)$ & $0.72(0.58-0.90)$ \\
\hline \multicolumn{5}{|l|}{ Antenatal visit } \\
\hline No & 1.00 & & 1.00 & \\
\hline Yes & $0.89(0.60-\mathrm{I} .32)$ & & $0.77(0.57-1.03)$ & \\
\hline
\end{tabular}

study showed that child's age in months, low socioeconomic status and gender (being a male child) were significant risk factors for stunting and severe stunting in North Maluku province of Indonesia. These results highlight the need for early intervention programmes aimed at reducing undernutrition in children, especially in the first two years of life.

\section{Competing interests}

The authors declare that they have no competing interests.

\section{Authors' contributions}

$\mathrm{R}$ and MJD designed the study. R, KA and SJB carried out the statistical analysis. R and KA wrote the manuscript. All authors made contributions to the interpretation of results and revised the manuscript for important intellectual content. All authors read and approved the final version of the manuscript.

\section{Acknowledgements}

This analysis is a part of the first author's thesis to fulfill the requirement for a PhD in Medicine at Newcastle University and we would like to thank Professor Cate D'Este, Director of the Centre for Clinical Epidemiology and Biostatistics, University of Newcastle for her excellent cooperation.

\section{References}

I. Sguassero Y, de Onis M, Carroli G: Community-based supplementary feeding for promoting the growth of young children in developing countries (Review). [http://www.cochrane.org/ reviews/en/ab005039.html]. (assessed I2 Dec., 2008)

2. Bhutta ZA: Why has so little changed in maternal and child health in south Asia? Br Med J 2000, 321:809-8I2.

3. Atmarita TSF: $\mathbf{A}$ summary of the current nutrition situation in Indonesia. Paper presented at Capacity and Leadership Development in Nutritional Sciences, Seoul Korea September 4 - 6, 2008.

4. Atmarita TSF: Nutrition problem in Indonesia. Paper presented at An Integrated International Seminar and Workshop on Lifestyle - Related Diseases, Gajah Mada University, 19 - 20 March, 2005.

5. Black RE, Morris SS, Bryce J: Where and why are i 0 million children dying every year? Lancet 2003, 36I(9376):2226-34.

6. Arifeen S, Black RE, Antelman G, Baqui A, Caulfield L, Becker S: Exclusive breastfeeding reduces acute respiratory infection and diarrhea deaths among infants in Dhaka slums. Pediatrics 200I, 108(4): E67.

7. Pelletier D, Frongillo EA: Changes in Child Survival Are Strongly Associated with Changes in Malnutrition in Developing Countries. Journal of Nutrition 2003, 133:107-II9.

8. Black R, for the Maternal and Child Undernutrition Study Group, et al: Maternal and child undernutrition: Global and regional exposures and health consequences. Lancet 2008, 37 I:243-360.
9. Penny M, Creed-Kanashiro HM, Robert RC, Narro MR, Caulfield LE, Black RE: Effectiveness of an educational intervention delivered through the health services to improve nutrition in young children: a cluster randomized controlled trial. Lancet 2005, 365:1863-1872.

10. Ayaya SO, Esamai FO, Rotich J, Olwambula AR: Socio-economic factors predisposing under five-year-old children to severe protein energy malnutrition at the Moi Teaching and Referral Hospital, Eldoret, Kenya. East African Medical Journal 2004, $81(8): 4|5-42|$.

II. Hautvast JL, et al.: Severe linear growth retardation in rural Zambian children: the influence of biological variables. $\mathrm{Am} J$ Clin Nutr 2000, 7 I (2):550-559.

12. World Health Organization: World Health Organization releases new Child Growth Standards. In "Standards confirm that all children worldwide have the potential to grow the same". WHO; Geneva; 2006.

13. Maluku-Utara: Pemerintahan Maluku Utara. 2008 [http:// en.wikipedia.org/wiki/North Maluku]. (assessed on 26 June 2008)

14. Razak TA: Assessment of Education, Health, Nutrition, Water and Sanitation and Protection Needs of Children in North Maluku. Hasanuddin University Press, Makassar, Indonesia; 2004.

15. Badan Pusat Statistik: Statistic Indonesia. [http://www.bps.go.id/]. (assessed on 12 Dec., 2008)

16. Ramli: Nutrition Status and Risk Factors for Malnutrition in Young Children in North Maluku province of Indonesia. In PhD thesis University of Newcastle, Australia; 2009.

17. World Health Organization: Physical Status: The use and interpretation of anthropometry, in WHO Technical Report Series No. 854. World Health Organ Tech Rep Ser 1995, 854: I-452.

18. Dean A, et al.: Epi-Info, version 5. Atlanta: Centers for Disease Control; 2000.

19. Filmer D, Pritchett LH: Estimating wealth effects without expenditure data - or tears: an application to educational enrolments in states of India. Demography 200I, 38: I I5-32.

20. World Health Organization: Global database on child and malnutrition. [http://www.who.int/nutgrowthdb/database/countries/ who standards/idn.pdf]. (assessed on 12 Dec. 2008)

21. ARIF G: Child Health and Poverty in Pakistan. The Pakistan Development Review 2004, 43(3):2 I I-238.

22. Demographic and Health Survey: Bangladesh Demographic and Health Survey. Calverton, Maryland: BPS and ORC Macro; 2003.

23. Demographic and Health Survey: India Demographic and Health Survey. Calverton, Maryland: BPS and ORC Macro; 2005.

24. National surveillance project: Nutrition and Health surveillance in Barisal division. Nutritional Surveillance Annual report, Bulletin No. 7. Dhaka; 2002.

25. Martorell R, Habicht JP: Growth in early childhood in developing countries. Human growth: A comprehensive treatise. 2nd edition. Edited by: Falkner, JM. New York: Plenum Press; 1986:24|-262.

26. Hoffman DJ, et al:: Energy expenditure of stunted and nonstunted boys and girls living in the shantytowns of Sao Paulo, Brazil. Am J Clin Nutr 2000, 72(4):1025-1031.

27. Prista A, et al.: Anthropometric indicators of nutritional status: implications for fitness, activity, and health in school-age children and adolescents from Maputo, Mozambique. Am J Clin Nutr 2003, 77(4):952-959. 
28. Moestue H, Huttly S: Adult education and child nutrition: the role of family and community. J Epidemiol Community Health 2008, 62(2): $153-159$.

29. Harpham T, De Silva MJ, Tuan T: Maternal social capital and child health in Vietnam. J Epidemiol Community Health 2006, 60(10):865-87I.

30. Addison CC: Nutrition and an active lifestyle. From knowledge to action. J Epidemiol Community Health 2006, 60(8):735.

\section{Pre-publication history}

The pre-publication history for this paper can be accessed here:

http://www.biomedcentral.com/1471-2431/9/64/prepub

Publish with Biomed Central and every scientist can read your work free of charge

"BioMed Central will be the most significant development for disseminating the results of biomedical research in our lifetime. "

Sir Paul Nurse, Cancer Research UK

Your research papers will be:

- available free of charge to the entire biomedical community

- peer reviewed and published immediately upon acceptance

- cited in PubMed and archived on PubMed Central

- yours - you keep the copyright 